女子短大生の時間带別の食品群及び栄養素等摂取量と 朝食欠食等に関する実態調査

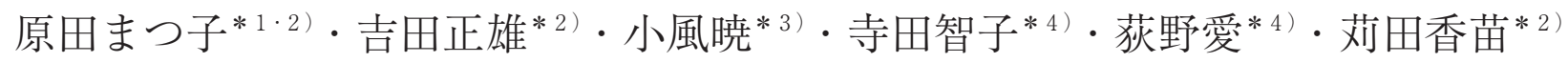

$\left({ }^{* 1}\right.$ 帝京短期大学, ${ }^{* 2}$ 杏林大学医学部, ${ }^{* 3}$ 昭和大学医学部, ${ }^{* 4}$ 東京家政大学)

\title{
Research on the intake of foods and nutrients by time zones in relation to the habit of skipping-breakfast in college women
}

\author{
Matsuko Harada*1.2), Masao Yoshida*2), Akatsuki Kokaze*3), \\ Tomoko Terada*4), Ai Ogino*4), Kanae Karita*2)
}

*1) Teikyo Junior College, 6-31-1, Honmachi, Shibuya-ku, Tokyo, Japan 151-0071

*2) Department of Public Health, Kyorin University School of Medicine, 6-20-2 Shinkawa, Mitaka-shi, Tokyo, Japan 181-8611

*3) Department of Public Health, Showa University School of Medicine, 1-5-8 Hatanodai, Shinagawa-ku, Tokyo, Japan, 142-8555

*4) Tokyo Kasei University, 1-18-1 Kaga Itabashi-ku, Tokyo, Japan 173-8602

$$
\begin{aligned}
& \text { *1) ₹ 151-0071 東京都渋谷区本町 6-31-1 } \\
& \text { *2) ₹181-8611 東京都三鷹市新川 6-20-2 } \\
& \text { *3) ₹ 142-8555 東京都品川区旗の台 1-5-8 } \\
& \text { *4) ₹ 173-8602 東京都板橋区加賀 1-18-1 }
\end{aligned}
$$

Young female students were divided into two groups, those who living at home and the others living away from home, and their consumption of food groups on different time zones and intake of various nutrients were compared. To find the relationship between the habit of skipping breakfast and time zones of meal intake, the subjects of the study-193 students majoring in food and nutrition or enrolled in a nutrition course at a junior college in Tokyo were requested to respond to "meal menu and intake time-based food frequency questionnaire (MMITQ)."

Compared with those students living at home $(n=133)$, the students living away from home $(n=60)$ were found to consume significantly less quantities of seafood and vegetables. Among the nutrients, the intake of vitamins $\mathrm{C}$ and $\mathrm{D}$ by the latter group was significantly lower $(p<0.05)$. The habit of breakfast-skipping was noted in $11.3 \%(n=15)$ of those students living at home and 13. $3 \%(n=8)$ of those living away from home, with no significant difference between the two groups. Among the breakfast-skippers who lived away from home, $68.9 \%$ of the daily energy was taken exclusively in the time zone after 4:00 pm. In the same time zone, their consumption of soy beans and soy products was greater than that of those living at home, and their intake of total lipids and magnesium was also high. There was no significant difference between the groups vis-à-vis the habits of snacking at night. Of $54.9 \%$ who habitually snacked at night, many consumed more than 2 types of food at night (20.7\%).

This study indicated the status of the diet that needs to be improved even for students who major in nutrition. Attention should be directed to the potential risk of nutrient deficiency that threatens those who live away from home and those habitually skip breakfast. 


\section{1. 緒言}

近年, 日本における朝食の欠食率は, 増加している ${ }^{1 \sim 4)}$ 。 平成 20 年国民健康 · 栄養調査 ${ }^{4)}$ では, 20 歳代の一人世帯 において欠食率が $26.2 \%$ と最も高いことが報告されてい る。また男女ともふだんの朝食の欠食が始まった時期は 20歳以降からの者が多く，女性では欠食者のうち 7 割以 上が高校卒業以降に欠食するようになると報告されてい る ${ }^{3)}$ 。女子大学生や女子短期大学生の欠食も同様に多 く ${ }^{5 \sim 8}$, それらが瘦身願望 ${ }^{9 \sim 11)}$ や生活習慣によるもので あるといわれている ${ }^{12 \sim 14)}$ 。この時期は親元から経済的に も生活面でも独立する者が多い年代で，今までの家庭に おける食に対する教育や環境が反映されているというよ り，むしろ自己の嗜好や生活を送ることそのものを優 先 $^{15)}$ してしまう傾向がある。そのため 20 代より朝食欠食 や不規則な食事習慣が始まることが推測され，健康への

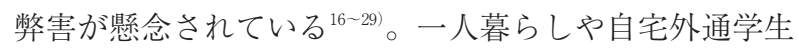
は, 家族と同居する学生と比較して朝食が欠食傾向で惣 菜などを手軽に利用し，昼食や食事を簡素化していると 共に食生活が不規則であることなどが推測され，その結 果栄養摂取量が少なく30 34)，食品群および栄養素等の摂 取のバランスに影響を及ぼしていると思われる。女子大 生および短大生の栄養摂取調査では, 生活時間 ${ }^{30-35)}$ や年 度別の栄養素等の摂取の推移 ${ }^{29}$, 36) が報告され, また自覚 症状 (不定愁訴 $)^{15 ~ 18)}$, 骨密度 ${ }^{25 ~ 29)}$, 便秘 ${ }^{22), 23)}$, 肥満およ び瘦身願望や体型と意識等との関連について多数の報告 がある ${ }^{12 \sim 14)}$ 。しかしこれらの栄養調査は，1日あるいは 朝食·昼食・夕食の食品群別摂取量 ·栄養素等摂取量か らの解析で，摂取時間帯別に分析した報告はない。摂取 時間帯別の食品群および栄養素等摂取量の把握は, 食事 の規則性や朝食欠食が他の摂取時間へ影響するか否かを 検討する上で意義があると思われる。そこで, 本研究で は, 女子短大生を対象に摂取時間帯別の食品群および栄 養摂取量等を自宅通学生と自宅外通学生との間で比較し, 朝食の欠食が他の時間帯の摂取に影響を及ぼしているか を明らかにすることを目的とした。

\section{2. 研究方法}

\section{（1） 調査時期・調査対象者および方法}

調査は2002年 7 月，2005年11月に実施した。調査対象 者は東京都内の某短期大学食物栄養専攻及び女子短期大 学部栄養科に在籍する学生270名（2002年：95名, 2005 年：175 名）に研究の趣旨を説明し同意を得た者を調査 対象とした。調査対象者のうち, 調査回答が不十分な者 と Kolmogorov-Smirnov 棄却検定により栄養素等摂取量 が特に離れたデータの值を有する者をエラーとみなして 除外し，193名を解析の対象とした。

本研究は倫理面や個人情報保護への配慮を盛り込んだ 実験計画書を作成し, 帝京短期大学研究倫理委員会の承 認を得た。
表 1 に示す通り, 対象者の年齢, 身長, 体重,BMI (Body Mass Index）の平均值 \pm 標準偏差值は2002年と2005年の 值が統計学的有意差が認められないため一括して全体で 分析を行った。

調査方法は「摂取時間帯を含む食事メニュー式栄養調 査票」（MMITQ：meal menu and intake time-based semiquantitive food frequency questionnaire ${ }^{37}$ を教室内で配 布し過去 1 年間の食事を思い出してもらい, 自己記入法 による調査を実施し，その場で回収した（回収率100\%）。

\section{(2) 分析方法}

1 日の摂取時間帯別食品群別摂取量, 推定エネルギー 摂取量および各栄養素摂取量の算出には先報 ${ }^{37)}$ と同様の 方法を用いた。さらに本研究では, 朝食, 昼食, 夕食の 時間帯を固定した概念でない 2 時間半間隔で 7 段階の質 問項目に分けた（～8 時29分，8時30分〜10時59分，11 時〜午後 1 時 29 分, 午後 1 時 30 分 3 時59分, 午後 4 時 $\sim$ 午後 7 時 29 分, 午後 7 時 30 分 $\sim 9$ 時59分, 午後10時以 降)。1日の摂取時間帯別食品群別摂取量, 摂取エネル ギー量および各栄養素摂取量を推定し，解析に用いた。 算出には先報 ${ }^{37)}$ と同様に, 各料理および惣菜別の 1 食分 における食品群別摂取量, 栄養素量等を基礎に, 以下の 算定方法で求めた。

$$
\begin{array}{ll}
A=a \times b \times c & B=\left\{A \times \frac{\mathrm{d}}{7}\right\} \times e \\
C & =\sum_{i=1}^{n} B
\end{array}
$$

$\mathrm{A}$ ：各料理または惣菜ごとの 1 日当たり摂取栄養素量 等

B：各料理または惣菜ごとの 1 日当たり摂取時間帯別 栄養素量等

C : 1 日の摂取時間帯別栄養素量等

$\mathrm{a}$ ：各料理または䈍菜等の一食分の器の栄養素量等

$\mathrm{b}$ : 目安量

c：摂取頻度

$\mathrm{d}$ ：各料理または惣菜等の摂取時間帯該当数

e : 摂取該当時間帯 (yes：1，no：0)

各栄養素等と食品群別時間帯別摂取量の分析には，時 間帯を 3 分位に分け,「11時未満」,「11時〜16時未満」, $\lceil 16$ 時以降」として解析をした。朝食欠食者は「11時未満」 に $\mathrm{MMITQ}^{37)}$ の質問各料理および惣菜等を摂取していな い者とし，また食事形態は料理および璱菜等から，セッ 卜型 (主食・主菜・副菜), セット型 + 果物・牛乳, 組 み合わせ型（主食・主菜または主食・副菜等の組合せ）, 1 品型（主食または主菜, 副菜, 牛乳·乳製品の何れか 1 つ選択)，菓子型の 5 形態に分類した。

さらに夜食を「22時以降」の時間帯として, 夜食の無, 夜食 1 品, 2 品以上の 3 群に分けた。外食の頻度は, 外 食無，ほとんど毎日とそれ以外とした。また 1 日の菓子 類の摂取回数は「1 回」と「2 回以上」の 2 分類で分析 
を行った。

自宅通学生（以下A群と略記）と自宅外通学生（以下 $\mathrm{B}$ 群と略記）について, 食事状況の 2 群間比較には $\chi^{2}$ 検定を，食品群別摂取量および各栄養素等摂取量間の 2 群間比較は Wilcoxonの順位和検定を，また 3 群間以上 の比較には Kruskal一Wallis 検定を用いた。解析には, SASver. 9.1を用い，有意水準を $5 \%$ とした。

\section{3. 結果}

\section{（1）住居形態}

表 1 に示すとおり，住居形態においてはA群が全体で 133名 $(68.9 \%)$, B群が60名 $(31.1 \%)$ で, B群の居住 形態の内訳は寮 9 名 $(15.0 \%)$, アパート49名 $(81.7 \%)$, その他 2 名 (3.3\%) であった。

表 1 対象者の属性

\begin{tabular}{lcrrrrrr}
\hline & & \multicolumn{2}{c}{ 2002年 $(\mathrm{n}=68)$} & \multicolumn{2}{c}{ 2005年 } & $(\mathrm{n}=125)$ & \multicolumn{2}{c}{ 全体 } & $(\mathrm{n}=193)$ \\
\cline { 3 - 8 } & & Mean & S.D & Mean & S.D & Mean & S.D \\
\hline 年齢 & (歳) & 19.1 & 2.5 & 19.2 & 1.6 & 19.1 & 2.0 \\
身長 & $(\mathrm{cm})$ & 158.1 & 5.4 & 158.1 & 5.2 & 158.1 & 5.2 \\
体重 & $(\mathrm{kg})$ & 51.2 & 5.6 & 51.0 & 6.3 & 51.1 & 6.0 \\
$\mathrm{BMI}$ & $\left(\mathrm{kg} / \mathrm{m}^{2}\right)^{* 3}$ & 20.4 & 1.7 & 20.4 & 2.3 & 20.4 & 2.1 \\
\hline \hline 住居形態 & $\mathrm{A}$ 群*4 & $48^{* 1}$ & $(73.5 \%)^{* 2}$ & $85^{* 1}$ & $(68.0 \%)^{* 2}$ & $133^{* 1}$ & $(68.9 \%)^{* 2}$ \\
& $\mathrm{~B}$ 群 $^{* 5}$ & $20^{* 1}$ & $(26.5 \%)^{* 2}$ & $40^{* 1}$ & $(32.0 \%)^{* 2}$ & $60^{* 1}$ & $(31.1 \%)^{* 2}$ \\
\hline
\end{tabular}

注) $\mathrm{n}$ : 人数

Mean : 平均値, S.D : 標準偏差值

*1実数， ${ }^{* 2} \mathrm{n}$ に対する\%

*3body mass index (BMI

${ }^{* 4} \mathrm{~A}$ 群：自宅通学生

${ }^{* 5} \mathrm{~B}$ 群 : 自宅外通学生

表 2 自宅通学生と自宅外通学生の食事状況

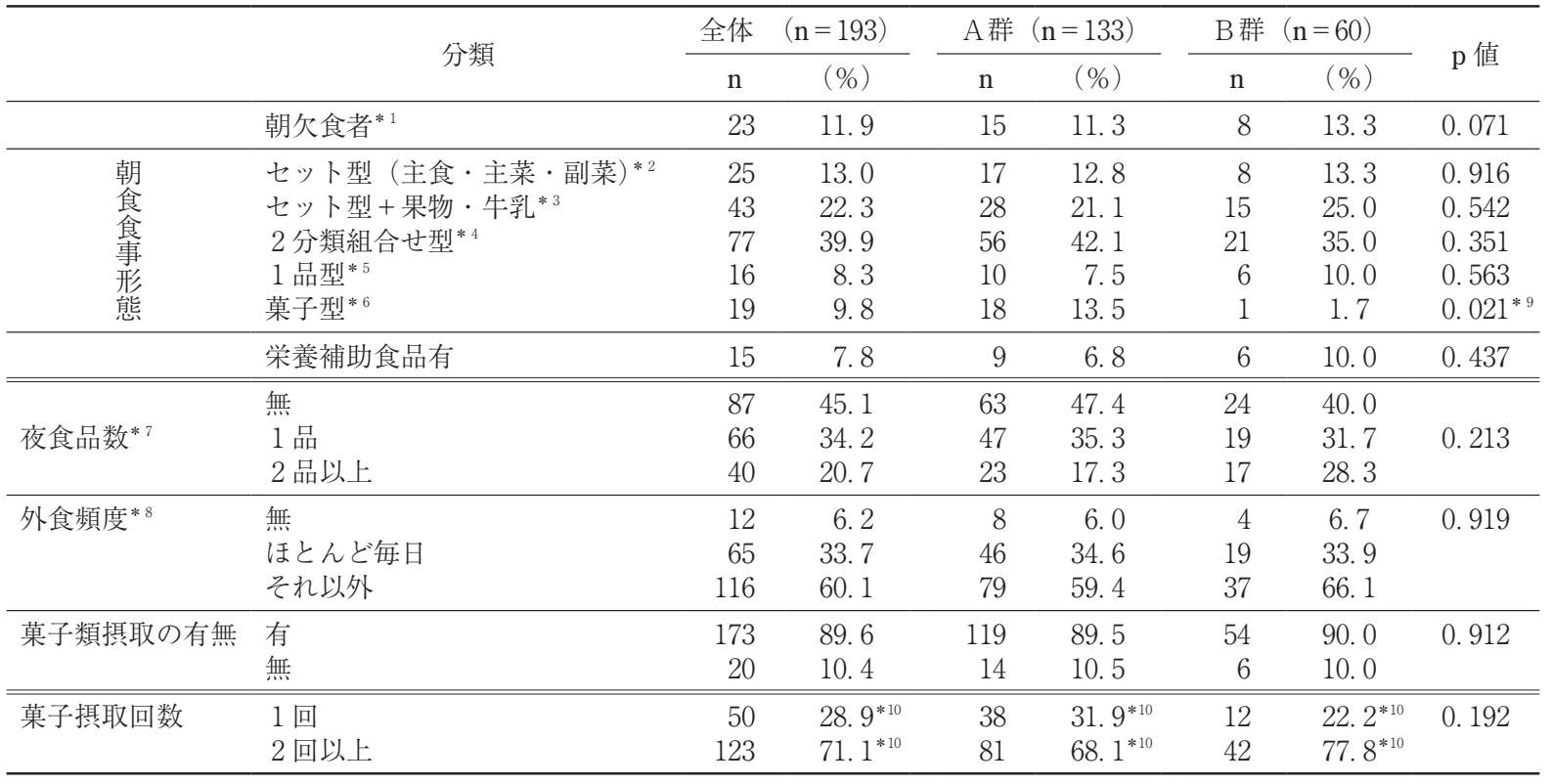

$\mathrm{n}$ : 人数

$\mathrm{A}$ 群：自宅通学生, B 群：自宅外通学生

"1 朝食欠食者：11時未満に MMITQ ${ }^{37}$ の質問各料理掞よび惣菜等を摂取していない者

*2ット型 (主食・主菜・副菜)：11時未満に $\mathrm{MMITQ}^{377}$ の質問各料理および䈍菜等から主食・主菜・副菜に分類したものを摂取

${ }^{* 3}$ セット型＋果物・牛乳：11時未満に MMITQ ${ }^{37}$ の質問各料理および物菜等から主食・主菜・副菜に分類できるものと果物と牛乳・乳製品を追加して摂取

${ }^{* 4}$ 主食・主菜または主食·副菜等の 2 分類を組合せ： 11 時未満に MMITQ ${ }^{37}$ の質問各料理抢よび惣菜等から主食・主菜または主食・副菜等の 2 分類を組合せを摂取

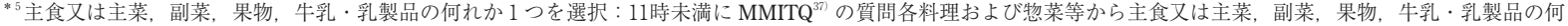
れか 1 つを選択摂取

*6 菓子型：11時未満に MMITQ ${ }^{37}$ の質問で菓子のみを摃取。

*7夜食：22時以降の時間带に摂取

*8外食の頻度：ほとんどなしを無, 毎日·週に $5 \sim 6$ 回をほとんど毎日, 月に $1 \sim 3$ 回・週 $1 \sim 2$ 回・週に $3 \sim 4$ 回をそれ以外とした。

*9イエーツの修正

*10菓子類摄取有に対する\%

検定 : $\chi^{2}$ 検定 


\section{（2）食事状況}

表 2 に示すとおり，朝食欠食の A 群は15名（11.3\%）, $\mathrm{B}$ 群 8 名 (13.3\%) であり，A群と B 群の割合に有意差 は認められなかった。朝食食事形態, 夜食品数, 外食頻 度, 菓子類摂取の有無および回数においてもいずれも住 宅形態による有意差は認められなかった。朝食の食事形 態は全体の約 $40 \%$ が主食と主菜か主食と副菜の組み合わ せで，主食・主菜・副菜のセット型は13.0\%であった。 夜食を 2 品以上摂っている者は $20.7 \%$ で，外食をほとん ど毎日摂取している者は $33.7 \%$ であった。菓子類を摂食 する者は $89.6 \%$ と多かった。

\section{（3）食品群別摂取量および栄養素等摂取量の比較}

食品群別摂取量は表 3 に示す通り，B群は魚介類（中 央值 $41.1 \mathrm{~g}$ ) とその他の野菜（中央值95. $5 \mathrm{~g}$ ) の摂取量 が $\mathrm{A}$ 群に比べて有意に少なかった（魚介類 $\mathrm{p}=0.003$,

その他の野菜 $\mathrm{p}=0.045)$ 。牛乳・乳製品以外の他の食品 群は, いずれも B 群では $\mathrm{A}$ 群に比べて摂取量が少ない傾 向であった。

栄養素等摂取量は表 4 に示す通り, B 群はカロテン (中 央值 $1835 \mu \mathrm{g}$ ), ビタミンC (中央值 $52 \mathrm{mg}$ ), ビタミン D (中央值3. $6 \mathrm{mg}$ ) が $\mathrm{A}$ 群に比べて有意に摂取量が低かっ た（カロテン $: p=0.021$, ビタミン $\mathrm{C}: \mathrm{p}=0.027$, ビタ ミン $\mathrm{D}: \mathrm{p}=0.010) 。 \mathrm{PFC}$ バランスは $\mathrm{A} ・ \mathrm{~B}$ 群共に脂肪 エネルギー比率が $30 \%$ をや超えていた。

\section{（4）時間帯別の食品群別および栄養素等摂取量の比較}

時間帯により食品群別摂取量が異なるかを検討するた めに，摂取時間帯別食品群別摂取量の A 群と B 群との比 較を表 5 に示した。 $\mathrm{B}$ 群の各食品群の摂取量は $\mathrm{A}$ 群に比 べて，いずれの時間帯も少ない傾向であった。特に魚介 類の摂取量は 11 時未満（中央值 $0.2 \mathrm{~g}$ ） と 16 時以降（中 央值26. $6 \mathrm{~g}$ ）の時間帯で $\mathrm{A}$ 群に比べて有意に少なかった
（11時未満 $: p=0.036,16$ 時以降 $: p=0.024 ） 。$

時間帯別栄養素等摂取量は表 6 に示す通り, B 群はA 群に比べて, 食品群別摂取量と同様に栄養素等の摂取量 がいずれの時間帯でも少ない傾向であった。特にB群は $\mathrm{A}$ 群に比べて16時以降にビタミン D (中央值 $1.7 \mathrm{mg}$ ）と カロテン (中央值 $1222 \mu \mathrm{g}$ ) の摂取量が有意に少なかっ た（ビタミン $\mathrm{D}: \mathrm{p}=0.022$ ，カロテン $: \mathrm{p}=0.049) 。$

（5）16時以降の食品群別摂取量と朝食の欠食有無別比 較

朝食の欠食が16時以降の食品群の摂取量に関連してい るかを検討するため, 朝食欠食の有無別の 16 時以降の食 品群別摂取量を表 7 に示した。A群の朝食欠食者は，朝 食喫食者に比べて全ての食品群の摂取量が有意に少なく， $\mathrm{B}$ 群と比較してもすべての食品群の摂取が少ない傾向に あった。一方 $\mathrm{B}$ 群は, 朝欠食の有無と各食品群の摂取量 との間に有意な差は認められなかった。しかし朝食欠食 者を $\mathrm{A}$ 群と B 群で比較すると， B 群はすべての食品群を 多く摂取する傾向にあり，特に大豆・大豆製品の摂取が $\mathrm{A}$ 群より多かった $(\mathrm{p}=0.023)$ 。 $\mathrm{A}$ 群の朝食欠食者は, 朝食喫食者に比べ食品群の摂取量が少なく， B 群の朝食 欠食者の方は多く摂取する傾向にある。

また栄養素等摂取量については表 8 に示した通り，A 群の朝食欠食者ではエネルギー量及び全ての栄養素摂取 量が朝食契食者に比べて有意に低く，朝食欠食者におい て A 群と B 群とを比較すると, 全ての栄養素等の摂取量 が低い傾向で, 特に総脂質 (中央值 $4.6 \mathrm{~g}$ ) とマグネシ ウム (中央值 $19 \mathrm{mg}$ ) 摂取量が有意に低かった（総脂質 $\mathrm{p}=0.049$ ，マグネシウム $\mathrm{p}=0.045) 。 \mathrm{~B}$ 群に限ると，朝 食欠食の有無による栄養素等の摂取量に有意差は認めら れなかった。

また 1 日のうちどの時間帯にエネルギーを多く摂取し

表 3 自宅通学生と自宅外通学生の食品群別摂取量

\begin{tabular}{|c|c|c|c|c|c|c|c|}
\hline \multirow{2}{*}{ 食品群 } & \multicolumn{2}{|c|}{ 全体（n=193） } & \multicolumn{2}{|c|}{ A群 $(\mathrm{n}=133)$} & \multicolumn{2}{|c|}{ B群 $(\mathrm{n}=60)$} & \multirow[t]{2}{*}{$\mathrm{p}$ 值 } \\
\hline & Median & $(25 \%-75 \%)$ & Median & $(25 \%-75 \%)$ & Median & $(25 \%-75 \%)$ & \\
\hline 肉類 & 67.0 & 43. 9-106. 1 & 70.6 & 48. $0-108.2$ & 58.3 & $42.2-101.7$ & 0.206 \\
\hline 魚介類 & 57.1 & 26. $2-95.5$ & 63.9 & $35.8-100.9$ & 41.1 & $21.7-73.5$ & 0.003 \\
\hline 卵類 & 41.0 & $22.3-75.0$ & 40.9 & $25.5-80.2$ & 42.3 & $15.4-62.4$ & 0.174 \\
\hline 大豆 · 大豆製品 & 32.0 & $12.8-59.3$ & 37.1 & $13.5-60.7$ & 30.9 & $10.5-57.6$ & 0.467 \\
\hline 牛乳·乳製品 & 91.4 & 33. 6-192. 1 & 86.4 & $32.6-177.8$ & 100.5 & 40. $0-221.9$ & 0.404 \\
\hline 緑黄色野菜 & 74.5 & $38.7-117.1$ & 79.1 & $42.9-118.6$ & 62.5 & 33. $7-107.4$ & 0.152 \\
\hline その他の野菜 & 136.3 & $76.6-225.9$ & 151.7 & $81.6-234.4$ & 95.5 & $69.4-200.7$ & 0.045 \\
\hline 果実類 & 32.8 & 7. $6-85.1$ & 33.9 & 9. $0-104.5$ & 20.9 & 4. 9-71. 6 & 0.102 \\
\hline 穀類 & 244.4 & 159. 1-326. 3 & 247.0 & 156. 9-326. 3 & 225.0 & 161. 4-313. 3 & 0.428 \\
\hline 芋類 & 24.5 & $13.4-37.1$ & 25.8 & 14. $7-40.0$ & 24.1 & 10. 7-33. 2 & 0.179 \\
\hline 油脂類 & 30.8 & $19.5-47.7$ & 31.0 & $20.3-50.0$ & 28.9 & $17.8-44.7$ & 0.319 \\
\hline
\end{tabular}

$\mathrm{A}$ 群 : 自宅通学生

B 群：自宅外通学生

Median：中央值

25\%-75\%：パーセンタイル值

検定：Wilcoxon の順位和検定（Mann-Whitney の U 検定 
表 4 自宅通学生と自宅外通学生のエネルギー及び主な栄養素摂取量

\begin{tabular}{|c|c|c|c|c|c|c|c|c|}
\hline \multirow{2}{*}{ 栄養素等 } & \multirow{2}{*}{ 単位 } & \multicolumn{2}{|c|}{ 全体（n=193） } & \multicolumn{2}{|c|}{ A 群 $(\mathrm{n}=133)$} & \multicolumn{2}{|c|}{ B 群（n=60） } & \multirow[t]{2}{*}{$\mathrm{p}$ 值 } \\
\hline & & Median & (25\%-75\%) & Median & (25\%-75\%) & Median & (25\%-75\%) & \\
\hline エネルギー & (kcal) & 1677 & (1136-2312) & 1786 & (1234-2330) & 1544 & (1090-2185) & 0.267 \\
\hline たんぱく質 & $(\mathrm{g})$ & 63.3 & (39. 9-84.0) & 65.0 & (44. 3-89.0) & 54.3 & (37. 9-81.0) & 0.186 \\
\hline 総脂質 & (g) & 60.2 & (39. 3-80.9) & 61.4 & $(41.0-80.6)$ & 51.6 & (37. 3-80.9) & 0.402 \\
\hline 炭水化物 & (g) & 227 & $(156.5-310.0)$ & 234.8 & $(158.5-310.3)$ & 202.9 & $(144.9-287.7)$ & 0.301 \\
\hline カルシウム & $(\mathrm{mg})$ & 456 & $(254-649)$ & 451 & $(245-655)$ & 458 & $(264-640)$ & 0.766 \\
\hline マグネシウム & $(\mathrm{mg})$ & 223 & (135-294) & 226 & $(137-315)$ & 178 & (135-290) & 0.353 \\
\hline カリウム & $(\mathrm{mg})$ & 2088 & (1264-2859) & 2181 & (1311-2941) & 1783 & $(1208-2787)$ & 0.392 \\
\hline 食物繊維 & $(\mathrm{g})$ & 11.5 & $(7.1-16.2)$ & 12.0 & (7. 4-16.5) & 9.3 & $(6.5-15.7)$ & 0.248 \\
\hline 鉄 & $(\mathrm{mg})$ & 6.9 & $(4.2-9.5)$ & 7.2 & $(4.5-9.7)$ & 5.7 & . 3) & 0.193 \\
\hline リン & $(\mathrm{mg})$ & 928 & $(583-1252)$ & 981 & (605-1275) & 844 & $(566-1248)$ & 0.334 \\
\hline カロテン & $(\mu \mathrm{g})$ & 2519 & (1427-3774) & 2776 & (1663-4081) & 1835 & (1267-3279) & 0.021 \\
\hline ビタミン B ${ }_{1}$ & $(\mathrm{mg})$ & 0.79 & $(0.52-1.18)$ & 0.84 & (0.53-1. 23) & 0.68 & (0.49-1 & 0.243 \\
\hline ビタミン $\mathrm{B}_{2}$ & $(\mathrm{mg})$ & 1. 12 & $(0.72-1.63)$ & 1.15 & $(0.75-1.67)$ & 1. 11 & $(0.71-1.54)$ & 0.575 \\
\hline ビタミンC & $(\mathrm{mg})$ & 69 & $(40-109)$ & 74 & $(43-118)$ & 52 & $(38-89)$ & 0.027 \\
\hline ビタミン D & $(\mathrm{mg})$ & 4.6 & $(2.8-7.4)$ & 5.1 & $(3.1-7.6)$ & 3.6 & $(2.0-5.6)$ & 0.010 \\
\hline 亜鉛 & $(\mathrm{mg})$ & 7.6 & $(5.0-10.5)$ & 8 & $(5.4-10.6)$ & 6.9 & $(4.6-9.8)$ & 0.235 \\
\hline 飽和脂肪酸 & $(\mathrm{g})$ & 17.14 & $(11.56-23.27)$ & 17. 47 & $(11.89-23.42)$ & 16.52 & (11. 31-22. 39) & 0.716 \\
\hline 多価不飽和脂肪酸 & $(\mathrm{g})$ & 13.1 & (8. 10-18.49) & 13.56 & (9. 58-18.49) & 11.9 & (7. 22-18. 88) & 0.221 \\
\hline ナトリウム & $(\mathrm{mg})$ & 4214 & $(2684-5612)$ & 4380 & $(2761-5768)$ & 3646 & $(2572-5393)$ & 0.252 \\
\hline (食塩相当量)* & $(\mathrm{g})$ & $(10.7)$ & $(6.8-14.3)$ & $(11.1)$ & $(7.0-14.7)$ & (9.3) & $(6.5-13.7)$ & \\
\hline たんぱく質エネルギー比率 & $(\%)$ & 15.1 & (14. 0-14.5) & 14.6 & (14. 4-15.3) & 14.1 & $(13.9-14.8)$ & \\
\hline 脂肪エネルギー比率 & $(\%)$ & 32.3 & $(31.1-31.5)$ & 30.9 & $(29.9-31.1)$ & 30.1 & $(30.8-33.3)$ & \\
\hline 炭水化物エネルギー比率 & $(\%)$ & 52.6 & $(54.9-54.0)$ & 54.5 & $(55.7-53.6)$ & 55.9 & $(55.3-51.9)$ & \\
\hline
\end{tabular}

A 群 : 自宅通学生

B 群 : 自宅外通学生

Median：中央値

$25 \%-75 \%$ : パーセンタイル值

*食塩相当量 $=($ ナトリウム $(\mathrm{mg}) \times 2.54) / 1000$

検定 :Wilcoxon の順位和検定（Mann-Whitney の U 検定）

表 5 摂取時間帯別の主な食品群別摂取量

(g)

\begin{tabular}{|c|c|c|c|c|c|c|c|c|}
\hline \multirow{2}{*}{ 食品群 } & \multirow{2}{*}{ 時間帯 } & \multicolumn{2}{|c|}{ 全体（n=193） } & \multicolumn{2}{|c|}{ A群 $(\mathrm{n}=133)$} & \multicolumn{2}{|c|}{ B群（n=60） } & \multirow[t]{2}{*}{$\mathrm{p}$ 值 } \\
\hline & & Median & $(25 \%-75 \%)$ & Median & $(25 \%-75 \%)$ & Median & $(25 \%-75 \%)$ & \\
\hline \multirow{3}{*}{ 肉類 } & 11時未満 & 0.8 & 0. 0-4. 2 & 0.8 & $0.0-4.5$ & 0.8 & $0.0-4.0$ & 0.498 \\
\hline & 11時～16時未満 & 15.5 & $6.3-32.8$ & 16.8 & $6.7-34.2$ & 14.1 & $5.4-28.4$ & 0.489 \\
\hline & 16時以降 & 44.5 & $24.6-66.6$ & 45.7 & $25.4-70.1$ & 41.6 & $23.6-62.6$ & 0.487 \\
\hline \multirow{3}{*}{ 魚介類 } & 11時未満 & 0.8 & $0.0-4.5$ & 0.9 & $0.0-6.5$ & 0.2 & $0.0-2.5$ & 0.036 \\
\hline & 11時～16時未満 & 5.3 & 1. $2-14.6$ & 5.7 & 1. $4-18.2$ & 4.6 & $0.8-13.2$ & 0.267 \\
\hline & 16時以降 & 37.7 & $17.8-67.2$ & 44.5 & $19.2-71.8$ & 26.6 & 13. $0-51.0$ & 0.024 \\
\hline \multirow{3}{*}{ 緑黄色野菜 } & 11時未満 & 2.4 & $0.0-13.5$ & 2.9 & $0.0-12.6$ & 0.6 & $0.0-15.5$ & 0.449 \\
\hline & 11時～16時未満 & 8.3 & 2. 9-21. 3 & 10.9 & 4. $7-24.5$ & 6.0 & 1. $4-18.4$ & 0.117 \\
\hline & 16時以降 & 51.6 & $21.3-76.8$ & 53.2 & $21.6-79.2$ & 38.7 & $20.4-71.3$ & 0.280 \\
\hline \multirow{3}{*}{ その他の野菜 } & 11時未満 & 7.9 & $0.8-29.1$ & 8.1 & $1.5-32.0$ & 6.9 & $0.0-25.0$ & 0.327 \\
\hline & 11時～16時未満 & 17.8 & $5.8-41.1$ & 18.3 & 6. $0-41.6$ & 17.0 & 5. $0-38.3$ & 0.635 \\
\hline & 16時以降 & 96.9 & $41.5-153.7$ & 108.1 & $42.2-165.9$ & 68.8 & $38.8-123.2$ & 0.072 \\
\hline \multirow{3}{*}{ 穀類 } & 11時未満 & 30.8 & $0.0-62.0$ & 33.0 & $0.2-64.0$ & 26.5 & $0.0-53.4$ & 0.368 \\
\hline & 11時～16時未満 & 82.9 & 34. 1-145. 3 & 88.1 & $36.1-146.4$ & 80.8 & $30.9-125.7$ & 0.456 \\
\hline & 16時以降 & 98.7 & $49.5-161.6$ & 99.6 & 43. $2-147.4$ & 90.9 & $51.3-168.0$ & 0.748 \\
\hline
\end{tabular}

A 群：自宅通学生

B 群 : 自宅外通学生

Median : 中央值

25\%-75\% : パーセンタイル值

検定 : Wilcoxon の順位和検定 (Mann-Whitney の U 検定) 
日本食生活学会誌 Vol.21 No.3（2010）

表 6 摂取時間帯別エネルギー及び主な栄養素摂取量

\begin{tabular}{|c|c|c|c|c|c|c|c|c|c|}
\hline \multirow{4}{*}{$\begin{array}{l}\text { 栄養素等 } \\
\text { エネルギー }\end{array}$} & \multirow{2}{*}{ 単位 } & \multirow{2}{*}{ 時間帯 } & \multicolumn{2}{|c|}{ 全体（n=193） } & \multirow{2}{*}{\multicolumn{2}{|c|}{$\frac{\text { A 群 }(\mathrm{n}=133)}{\operatorname{Median}(25 \%-75 \%)}$}} & \multirow{2}{*}{\multicolumn{2}{|c|}{$\frac{\mathrm{B} \text { 群 }(\mathrm{n}=60)}{\operatorname{Median}(25 \%-75 \%)}$}} & \multirow{2}{*}{$\mathrm{p}$ 值 } \\
\hline & & & \multicolumn{2}{|c|}{ Median $(25 \%-75 \%)$} & & & & & \\
\hline & & 11時未満 & 289 & $92-510$ & 296 & $120-517$ & 258 & $64-457$ & 0.280 \\
\hline & (kcal) & 11時～16時未満 & 468 & $224-739$ & 493 & $225-781$ & 426 & $228-675$ & 0.406 \\
\hline & & 16時以上 & 818 & $490-1255$ & 859 & $490-1225$ & 689 & $478-1367$ & 0.836 \\
\hline & & 11時未満 & 10.6 & 3.2 & 11.0 & 198 & 8 & 9.5 & 0.384 \\
\hline たんぱく質 & $(\mathrm{g})$ & 11時～16時 & 14.9 & $6.4-$ & 15.1 & $6.4-23.7$ & 13.9 & $6.6-22.4$ & 0.377 \\
\hline & & 16時以上 & 32.1 & $16.8-48.2$ & 34.0 & 16. $6-48.0$ & 27.5 & $17.4-49.8$ & 0.45 \\
\hline & & 11時未満 & 8.6 & 2. $0-15.9$ & 9.1 & 3. $2-15.9$ & 7.4 & $0.7-15.9$ & 0.567 \\
\hline & (g) & 11時～16時未満 & 13.5 & 5. 6-24. 1 & 14 & 7. $2-24.2$ & 12.4 & $5.4-22.9$ & 0.522 \\
\hline & & 16時以上 & 31.7 & $18.3-50.5$ & 34.8 & $17.8-49.1$ & 27.3 & $18.6-56.3$ & 0.692 \\
\hline & & 11時未満 & 38.5 & $11.6-69.6$ & 41.1 & $12.7-76.2$ & 33.4 & $9.6-60.6$ & 0.184 \\
\hline 炭水化物 & $(\mathrm{g})$ & 11時～16時未満 & 65.5 & $34.6-104.9$ & 67.5 & $34.6-110.6$ & 60.8 & $34.2-94.6$ & 0.373 \\
\hline & & 16時以上 & 94 & $57.8-147.4$ & 97.2 & $54.6-142.1$ & 82.6 & $61.4-159.1$ & 0.877 \\
\hline & (O) & 11時未満 & 99 & $15-358$ & 91 & $16-308$ & 155 & $8-406$ & 0.703 \\
\hline , & $(\mu g)$ & 11時～16時未満 & 396 & $121-814$ & 414 & $118-861$ & 354 & $141-666$ & 0.421 \\
\hline & & 16時以上 & 1746 & 817-2916 & 2043 & 974-2972 & 1222 & $754-2522$ & 0.049 \\
\hline ビタミンC & (mg) & 11時未満 & 7.8 & $2-16$ & 8 & $3-1$ & 6 & $1-1$ & 0.196 \\
\hline & & 11時～16時未満 & 13 & $6-23$ & 14 & $7-24$ & 12 & $5-19$ & 0.239 \\
\hline & & 16時以上 & 40 & $22-67$ & 48 & $23-73$ & 31 & $20-57$ & 0.071 \\
\hline ビタミン D & $(\mathrm{mg})$ & 11時未満 & 0.7 & $0.0-1.9$ & 0.8 & $0.1-2.2$ & 0.6 & $0.0-1.4$ & 0.161 \\
\hline & & 11時～16時未満 & 0.7 & $0.3-1.6$ & 0.7 & $0.2-1.6$ & 0.7 & $0.3-1.4$ & 0.708 \\
\hline & & 16時以上 & 2.4 & $0.9-4.1$ & 2.5 & 1. $1-4.8$ & 1.7 & $0.8-2.9$ & 0.022 \\
\hline
\end{tabular}

A 群 : 自宅通学生

B 群：自宅外通学生

Median：中央值

$25 \%-75 \%$ : パーセンタイル值

検定 :Wilcoxon 順位和検定（Mann-Whitney の U 検定）

表7 16時以降の食品群別摂取量と朝食の欠食有無別比較

\begin{tabular}{|c|c|c|c|c|c|c|c|c|c|c|c|c|}
\hline \multirow{3}{*}{ 食品群 } & \multicolumn{4}{|c|}{ A群 $\quad(\mathrm{n}=133)$} & \multicolumn{4}{|c|}{ B 群 $(\mathrm{n}=60)$} & \multirow{2}{*}{\multicolumn{4}{|c|}{$\mathrm{p}$ 值 }} \\
\hline & \multicolumn{2}{|c|}{$\mathrm{a}$ ：朝食欠食者（n=15） } & \multicolumn{2}{|c|}{ b: 朝食喫食者（n=118） } & \multicolumn{2}{|c|}{$\mathrm{c}$ ：朝食欠食者 $(\mathrm{n}=8)$} & \multicolumn{2}{|c|}{$\mathrm{d}$ : 朝食契食者 $(\mathrm{n}=52)$} & & & & \\
\hline & Median & $(25 \%-75 \%)$ & Median & $(25 \%-75 \%)$ & Median & $(25 \%-75 \%)$ & Median & $(25 \%-75 \%)$ & $\mathrm{a}-\mathrm{b}$ & $c^{-}-d$ & $\mathrm{a}-\mathrm{c}$ & $b-d$ \\
\hline 肉類 & 4.3 & $0.0-36.5$ & 47.4 & $28.6-71.6$ & 31.8 & 19. 3-92. 9 & 43.5 & 23. 6-61. 5 & 0.002 & 0.982 & 0.218 & 0.198 \\
\hline 魚介類 & 3.5 & $0.0-34.6$ & 45.9 & 23. 7-74. 4 & 32.6 & 11. $7-48.6$ & 26.6 & 13. $0-51.0$ & 0.001 & 0.888 & 0.154 & 0.005 \\
\hline 卵類 & 2.9 & $0.0-13.1$ & 17.1 & $8.2-27.7$ & 7. 2 & 3. $1-32.2$ & 15.6 & 5. 8-23. 0 & 0.001 & 0.384 & 0.185 & 0.359 \\
\hline 大豆 · 大豆製品 & 0.9 & $0.0-5.4$ & 24.1 & $12.1-49.1$ & 18.5 & 4. $6-51.3$ & 20.2 & 5. 9-40. 9 & 0.0003 & 0.862 & 0.023 & 0.166 \\
\hline 牛乳·乳製品 & 4.0 & $0.1-19.4$ & 35 & $15.5-67.7$ & 20.0 & 4. $3-64.1$ & 34.4 & $12.8-68.4$ & $\mathrm{p}<0.001$ & 0.396 & 0.086 & 0.762 \\
\hline 緑黄色野菜 & 6.8 & $0.0-31.2$ & 56 & $29.4-86.1$ & 28.2 & 7. $0-64.3$ & 39.9 & $21.4-71.3$ & $\mathrm{p}<0.001$ & 0.249 & 0.081 & 0.111 \\
\hline その他の野菜 & 23.0 & $0.0-42.0$ & 110.8 & 59. $7-175.3$ & 49.0 & $11.2-145.5$ & 71.5 & 43. $7-123.2$ & $\mathrm{p}<0.001$ & 0.361 & 0.137 & 0.014 \\
\hline 果実類 & 0.1 & $0.0-8.0$ & 13.8 & $0.5-55.2$ & 0.5 & $0.0-45.1$ & 8.4 & $0.6-31.4$ & 0.001 & 0.365 & 0.707 & 0.212 \\
\hline 穀類 & 12.1 & $0.3-99.6$ & 107. 1 & 53. $4-150.9$ & 67.1 & $33.8-147.9$ & 92.2 & $54.4-168.0$ & 0.005 & 0.460 & 0.138 & 0.988 \\
\hline 芋類 & 3.8 & $0.0-8.8$ & 18.2 & 11. $1-27.1$ & 16.3 & 1. $7-25.9$ & 13 & 8. 1-22. 2 & $\mathrm{p}<0.001$ & 0.992 & 0.283 & 0.036 \\
\hline 油脂類 & 2.1 & $0.0-7.6$ & 20 & 11. $2-30.7$ & 11.9 & 4. $3-28.8$ & 15.6 & 7. 9-27. 0 & $\mathrm{p}<0.001$ & 0.460 & 0.065 & 0.274 \\
\hline
\end{tabular}

$\mathrm{A}$ 群 : 自宅通学生

B 群 : 自宅外通学生

Median：中央值

$25 \%-75 \%$ : パーセンタイル值

検定 : Kruskal-Wallis 検定 
表 8 16時以降の栄養素等摂取量と朝食の欠食有無別比較

\begin{tabular}{|c|c|c|c|c|c|c|c|c|c|c|c|c|c|}
\hline \multirow{3}{*}{ 栄養素等 } & \multirow{3}{*}{ 単位 } & \multicolumn{4}{|c|}{ A 群 $(\mathrm{n}=133)$} & \multicolumn{4}{|c|}{ B群 $(\mathrm{n}=60)$} & \multirow{2}{*}{\multicolumn{4}{|c|}{$\mathrm{p}$ 值 }} \\
\hline & & \multirow{2}{*}{\multicolumn{2}{|c|}{$\frac{\text { a: 朝食欠食者 }(\mathrm{n}=15)}{\text { Median }(25 \%-75 \%)}$}} & \multirow{2}{*}{\multicolumn{2}{|c|}{$\frac{\mathrm{b}: \text { 朝食契食者 }(\mathrm{n}=118)}{\text { Median }(25 \%-75 \%)}$}} & \multirow{2}{*}{\multicolumn{2}{|c|}{$\frac{\mathrm{c}: \text { 朝食欠食者 }(\mathrm{n}=8)}{\text { Median }(25 \%-75 \%)}$}} & \multirow{2}{*}{\multicolumn{2}{|c|}{$\frac{\mathrm{d} \text { : 朝食契食者 }(\mathrm{n}=52)}{\text { Median }(25 \%-75 \%)}$}} & & & & \\
\hline & & & & & & & & & & $\mathrm{a}-\mathrm{b}$ & $c^{-}-d$ & $\mathrm{a}-\mathrm{c}$ & $b-d$ \\
\hline エネルギー & (kcal) & 84 & $18-545$ & 910 & $547-1228$ & 536 & $277-1538$ & 710 & $518-1322$ & $\mathrm{p}<0.001$ & 0.145 & 0.107 & 0.428 \\
\hline たんぱく質 & $(\mathrm{g})$ & 4. 2 & $0.4-20.7$ & 34.9 & $21.7-48.2$ & 20.9 & 9. $0-61.6$ & 29.2 & 18. $2-47.4$ & 0.001 & 0.447 & 0.107 & 0.164 \\
\hline 総脂質 & $(\mathrm{g})$ & 4.6 & $0.6-16.4$ & 36 & $23.9-49.6$ & 20.7 & 11. $7-66.2$ & 28.1 & 19. $3-53.3$ & $\mathrm{p}<0.001$ & 0.609 & 0.049 & 0.281 \\
\hline 炭水化物 & $(\mathrm{g})$ & 12.4 & $2.8-76.3$ & 102.1 & 63. 1-145. 5 & 63.4 & $32.8-168.0$ & 85.3 & $62.7-159.1$ & 0.001 & 0.580 & 0.114 & 0.745 \\
\hline カルシウム & $(\mathrm{mg})$ & 33 & 6-69 & 237 & $135-354$ & 122 & $36-497$ & 197 & $124-348$ & $\mathrm{p}<0.001$ & 0.396 & 0.076 & 0.437 \\
\hline マグネシウム & $(\mathrm{mg})$ & 19 & $1-56$ & 133 & 81-189 & 69 & $28-238$ & 101 & 71-185 & $\mathrm{p}<0.001$ & 0.415 & 0.045 & 0.119 \\
\hline カリウム & $(\mathrm{mg})$ & 243 & $8-561$ & 1289 & 822-1893 & 657 & $266-2223$ & 1066 & $677-1707$ & $\mathrm{p}<0.001$ & 0.480 & 0.061 & 0.091 \\
\hline 食物繊維 & $(\mathrm{g})$ & 1.2 & $0.0-2.6$ & 7.0 & 4. $2-10.4$ & 3.1 & 1. $4-12.9$ & 5.3 & 4. $0-9.9$ & $\mathrm{p}<0.001$ & 0.500 & 0.065 & 0.186 \\
\hline 鉄 & $(\mathrm{mg})$ & 0.7 & $0.0-1.7$ & 4. 2 & $2.4-5.9$ & 2.2 & $0.8-7.4$ & 3.1 & $2.1-5.8$ & $\mathrm{p}<0.001$ & 0.361 & 0.075 & 0.137 \\
\hline リン & $(\mathrm{mg})$ & 60 & 6-269 & 501 & $327-712$ & 302 & $118-921$ & 418 & $262-727$ & $\mathrm{p}<0.001$ & 0.520 & 0.087 & 0.237 \\
\hline カロテン & $(\mu \mathrm{g})$ & 233 & $1-1030$ & 2210 & $1178-3040$ & 553 & $317-2530$ & 1236 & $828-2522$ & $\mathrm{p}<0.001$ & 0.123 & 0.137 & 0.009 \\
\hline ビタミン B 1 & $(\mathrm{mg})$ & 0.05 & $0.01-0.22$ & 0.46 & $0.29-0.69$ & 0.39 & $0.11-0.80$ & 0.39 & $0.26-0.67$ & $\mathrm{p}<0.001$ & 0.736 & 0.113 & 0.253 \\
\hline ビタミン $\mathrm{B}_{2}$ & $(\mathrm{mg})$ & 0.07 & $0.01-0.23$ & 0.62 & $0.37-0.85$ & 0.48 & $0.11-1.09$ & 0.5 & $0.30-0.82$ & $\mathrm{p}<0.001$ & 0.794 & 0.081 & 0.261 \\
\hline ビタミンC & $(\mathrm{mg})$ & 11 & $1-17$ & 51 & 29-79 & 36 & 8-91 & 31 & $21-56$ & $\mathrm{p}<0.001$ & 0.794 & 0.093 & 0.006 \\
\hline ビタミン D & $(\mathrm{mg})$ & 0.7 & $0.0-1.9$ & 2.6 & 1. 4-5. 0 & 1.2 & $0.2-3.4$ & 1.8 & $0.8-2.9$ & 0.001 & 0.535 & 0.518 & 0.007 \\
\hline 亜鉛 & $(\mathrm{mg})$ & 0.4 & $0.0-2.4$ & 4. 2 & $2.7-5.8$ & 2.2 & 1. $1-7.2$ & 3.7 & $2.3-5.9$ & $\mathrm{p}<0.001$ & 0.440 & 0.164 & 0.259 \\
\hline 飽和脂肪酸 & $(\mathrm{g})$ & 0.89 & $0.22-0.98$ & 9.11 & $6.14-12.47$ & 6.04 & 3. $05-16.07$ & 7.4 & $5.52-14.34$ & 0.001 & 0.609 & 0.107 & 0.654 \\
\hline 多価不飽和脂肪酸 & $(\mathrm{g})$ & 1. 48 & $0.04-3.85$ & 8.66 & $5.51-12.41$ & 4.6 & $2.30-17.13$ & 6.73 & 4. $17-11.20$ & 0.001 & 0.572 & 0.107 & 0.13 \\
\hline ナトリウム & $(\mathrm{mg})$ & 318 & $4-1278$ & 2420 & $1408-3524$ & 1602 & $538-4300$ & 1836 & $1351-2889$ & 0.001 & 0.679 & 0.081 & 0.176 \\
\hline (食塩相当量)* & $(\mathrm{g})$ & $(0.8)$ & $(0.0-3.2)$ & $(6.1)$ & $(3.6-9.0)$ & $(4.1)$ & $(1.4-10.9)$ & $(4.7)$ & $(3.4-7.3)$ & & & & \\
\hline
\end{tabular}

A 群 : 自宅通学生

B 群：自宅外通学生

Median：中央値

$25 \%-75 \%$ : パーセンタイル值

*食塩相当量 $=($ ナトリウム $(\mathrm{mg}) \times 2.54) / 1000$

検定 : Kruskal-Wallis 検定

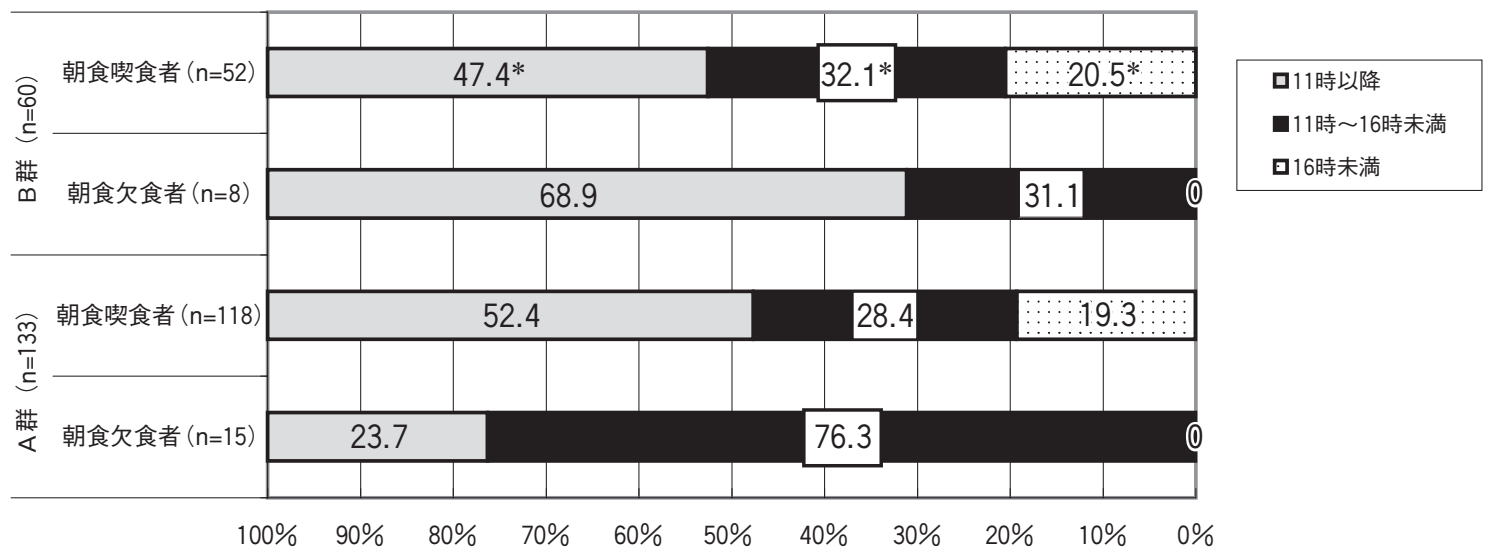

図 1 朝食の欠食有無と時間帯別摂取エネルギー割合の比較

注）* 自宅外通学生の朝食契食者52名の 1 日の摂取エネルギーは1498kcalで，その内訳は11時未満：307kcal,

11時〜16時未満：481kcal，16時以降：710kcalである。したがって，揁取エネルギー割合は11時未満：(307/1498） × 100=20.5（\%）

11時〜16時未満：(481/1498） × 100=32.1（\%)，16時以降：(710/1498） × 100=47.4（\%) である。

ているか，規律性を検討する目的で図 1 を示した。A群 の朝食欠食者は 1 日のうちのどの時間帯にエネルギー捸 取するかを比較すると，11時〜16時未満の時間帯が $76.3 \%$ と多く，16時以降では23.7\%と少なかった。一方 $\mathrm{B}$ 群の朝食欠食者は 16 時以降に $68.9 \%$ と多く16時以降に 集中してエネルギーを摂っていた。 $\mathrm{A}$ 群およびB群の朝 食喫食者は11時未満が約20\%，11時〜16時未満が約30\%， 16時以降の時間帯に約50\%であり，16時以降の時間帯で エネルギー摂取をするなど偏重傾向がみられた。

\section{4. 考察}

対象者の身体状況は，身長，体重，BMI ともに平成 14年と平成17年の国民健康・栄養調査 ${ }^{2)}$, 38) の20歳の体型 と近似しており，標準的であった。朝食欠食は 17 年国民 健康・栄養調査結果 ${ }^{2)}$ の同年代女子 $23.5 \%$ に比べて全体 で11.9\%，A群11.3\%，B群13.3\%と少なかったが，栄 養学科の自宅外通学生の朝食欠食率は時枝 ${ }^{32}$ らの調査に おいても13.1\%と同様の傾向がみられた。これは栄養学 
科の学生が同年代の一般人より，規則正しい食習慣につ いてょり自覚しているためと推測される。夜食は54.9\% の者が摂取しており，そのうち2 品以上摂取している者 が20.7\%で，A群， B 群の区別なく夜食習慣があり問題 となる食行動の 1 つといえる。夕食時刻が 21 時以降の遅 い食習慣は就寝時刻が遅くなり朝食を欠食する者が多く BMI, 収縮期血圧に影響が現れ, 肥満, 高血圧症の一要 因になることが示唆される報告があり ${ }^{43)}$, 本研究対象者 についても「午後10時以降」の食事習慣を有する者が $54.9 \%$ と多く，そのうち朝食欠食者は $8.5 \%$ てたことか らこれらの影響が危惧される。

$\mathrm{A}$ 群と B 群の食品群および栄養素等の摂取状況は, B 群は $\mathrm{A}$ 群に比較して魚介類やその他の野菜の摂取が有意 に少なく，それらはビタミン C, ビタミン D摂取量の有 意な低值に影響していると考えられた。特に魚介類の摂 取量は11時未満と16時以降の時間帯には少なく, 昼間に 摂取する傾向はあるものの手軽に料理できる肉や卵料理 を選ぶことも推測され，ビタミン D摂取量等の低值につ ながったものと思われる。また B 群のその他の野菜の摂

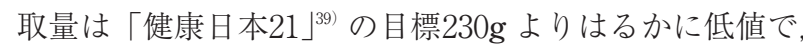
ビタミン C 摂取量が低く, 緑黄色野菜と果物類摂取量は 有意差は認められないものの, カロテン摂取量が低かっ た。小野らの調査 ${ }^{30)}$ では自宅外通学生は自宅通学生に比 べて緑黄色野菜や淡色野菜, 魚介類等をほとんど食べな い者の割合が多い報告がされている。本調査においても 摂取量からみると, 同様に栄養状況が悪いことが観察さ れた。B群の11時未満や16時以降の食事摂取量が全体の 食品群摂取量の低值と共に各栄養素摂取量に影響を及ぼ したと推測される。また, 日本人の食事摂取基準（2010 年版 $)^{40)}$ と比較すると, A 群および B 群はカルシウム, マグネシウム, 鉄, ビタミン C, ビタミン $\mathrm{D}$, 食物繊維 の習慣的摂取不足がみられた。一方，総脂質，飽和脂肪 酸, 食塩相当量の摂取量は目標量を超過していたため, 生活習慣病予防の観点からも食生活の改善が望まれる。

また A 群の朝食欠食者は16時以降の時間帯に全ての食 品群摂取量および栄養素等摂取量が少ないことが認めら れ，1日のどの時間帯にエネルギーを摂るかを比較する と11時〜16時未満には76.3\%と多く，16時以降の時間帯 には23.7\%と少なく，11時〜16時未満に集中して摂取し ていた。加來らの調査 ${ }^{41)}$ では自宅通学生の食事は家族に 依存する傾向にあることを報告している。また内閣府の 大学生実態調査 ${ }^{42}$ では朝食欠食者の栄養のバランスに対 する意識は低い。本調査対象者の意識調査はしていない ものの加來ら ${ }^{41)}$ や内閣府の実態調査 ${ }^{42}$ から A 群の朝食欠 食者は家族に依存する食事傾向にあるために栄養量等に 関する意識が低く，16時以降の食品群および栄養素等摂 取量に配慮する意識が働かないことが推測される。また $\mathrm{B}$ 群は朝食の欠食の有無に関係なく $\mathrm{A}$ 群に比べて栄養素 量等の摂取が低いことが明らかになり, 将来の健全な母 性機能の遂行面 ${ }^{30)}$ からも思慮しなければならない問題と
いえる。質問項目数が多かったため, 対象者が過小に申 告した可能性も捨てきれないが，A群（自宅通学者）の 調査結果で16時以降も少食であった朝食欠食者は, ダイ エット志向があるものと推測される。また B 群は料理を 作るのが面倒であったり, 寝坊するなどの理由で朝食を 食べないことが推測される。内閣府の大学生の実態調 査 ${ }^{42)}$ では, 朝食の欠食は「もっと寝ていたい」,「身支度 の準備で忙しい」,「食べるのが面倒」「時間がもったい ない」等の理由が約 3 割以上を占め, 大学生が食事を重 要に認識していないといえる。またB 群で朝食欠食者は, 16時以降の時間帯に大豆・大豆製品の摂取量が多く，手 軽な豆腐や納豆などをよく食べている傾向で, 同時間帯 にエネルギーを摂取している割合が $68.9 \%$ と，1 日のう ち16時以降に偏重したエネルギー摂取をしていることが 推測される。

$\mathrm{B}$ 群では魚介類, その他の野菜，芋類の摂取量が $\mathrm{A}$ 群 に比ベ少なく, カロテンやビタミン C, ビタミン Dの摂 取量が低值を示し, 朝食欠食の有無が16時以降の食事摂 取に少なくとも影響していることが示唆された。自炊す る学生では, 緑黄色・淡色野菜や魚介類等の摂取が少な い（緑黄色野菜57\%, 淡色野菜 $24.1 \%$, 魚介類 $65.8 \%$ ) ことが既に報告されており ${ }^{30)}$ ，栄養について正しい知識 と食行動の変容を図ることが必要である。

朝食欠食や食事習慣の乱れは，サーカディアン・リズ ムへの乱れや食欲への影響, メタボリックシンドローム 等の発症 ${ }^{42}$ (5) や記憶力・疲労等にも影響を及ぼすことが 指摘されている ${ }^{17 \sim 99,46)}$ 。同じカロリーの食事内容を夕食 の時間帯と朝食の時間帯に摂取した場合，夕食の時間帯 に摂取した者の方が体重増加が現れる ${ }^{43)}$ 。Purslow L. R. ら ${ }^{46)}$ は, 中年男女を対象にしたコホート研究で朝食 におけるエネルギー摂取量が多い者ほど体重増加が少な いことを報告している。また，肥満症の患者では，夜に 集中的に食べ，朝は食欲不振に陥るため食べず，消費工 ネルギーに比べ摂取エネルギーが過剩となる食生活を送 ることが特徵的である。これを Stunkard A. J. は，夜食 症 (The Night-eating Syndrome) と名づけている。 食時間が遅い食習慣は BMI，収縮期血圧が高くなり， 肥満や高血圧症の一要因となることが報告されている ${ }^{48)}$ さらに, 遅い夕食時間帯の摂取の持続は, 血清メラトニ ン，レプチン濃度の上昇が抑制され，睡眠障害を起こす ことに関連性があることを金子らは報告している 研究の, 食事摂取の規律性について, 朝食喫食者は $\mathrm{A}$ 群 及び $\mathrm{B}$ 群に関わりなく規則的傾向が推測されるが, 朝食 欠食者において B 群は16時以降に，A群は11時〜16時未 満に食事が集中していることが推測される。B群および $\mathrm{A}$ 群にかかわらず，現代の若年者の食生活の実態を現し た結果であると思われ，生活習慣病予防の観点からも， 規則正しい時間帯での食事摂取と食習慣の改善 ·食行動 の変容を促す教育の推進が求められる。若年者の食生活 習慣が将来の生活習慣病の発症にどのような影響を及ぼ 
すか, 今後個々のリスクファクターを朝食欠食の背景等 も含め詳細に検討したい。

\section{まとめ}

東京都内の某短期大学食物栄養専攻および栄養科に在 籍する学生193名を対象に,「摂取時間帯を含む食事义 ニュー式栄養調查票」を用い, 自宅通学生 ( $\mathrm{A}$ 群) と自 宅外通学生 (B 群) の食品群および栄養摂取量等を摂取 時間帯別に比較し, 朝食欠食が他の時間帯摂取に影響を 及ぼすかについて検討を行い，以下の結果が得られた。 1） B 群は，A群に比較し魚介類とその他の野菜の摂 取量が有意に少なく，栄養素においてはビタミンC, ビ タミンDの摂取が低值であった。

2） $\mathrm{A}$ 群の朝食欠食者は，1日のうちエネルギーを11 時〜16時未満に $76.3 \%$ と多く，16時以降には $23.7 \%$ と少 ない。

3） B 群の朝食欠食者は，1 日のうちエネルギーを 16 時以降に68.9\%と多く摂っていた。同時間帯の大豆・大 豆製品の摂取量がA群の朝食欠食者よりやや多く, 総脂 質・マグネシウムの摂取量が高值であった。

4）夜食習慣については，自宅通学の有無にかかわら ず有意差はなく，夜食習慣がある者は全体の $54.9 \%$ であ り, 夜食時に 2 品以上の食品を摂取している者が $20.7 \%$ であった。

栄養学を専攻する学生においても，改善すべき食生活 の実態が明らかになった。特に自宅外通学生や朝食欠食 者で潜在的な栄養素の欠乏が危惧され，生活習慣病の予 防の観点からも，規則的な食事摂取と食行動の変容を促 す教育の必要性がある。

\section{謝 辞}

本研究を行うにあたり，ご指導・ご助言を賜りました 杏林大学医学部衛生学公衆衛生学教室の故高島豊先生に 厚く御礼申し上げます。

\section{参考文献}

1）健康 - 栄養情報研究会編 厚生労働省 平成16年国民健 康・栄養の現状, p46, 第一出版, 東京 (2006)

2）健康・栄養情報研究会編厚生労働省 平成17年国民健 康・栄養の現状，p54，第一出版，東京（2007）

3 ）健康・栄養情報研究会編厚生労働省 平成18年国民健 康・栄養の現状, p67, 第一出版, 東京 (2009)

4 ）厚生労働省健康局総務課生活習慣病対策室，平成20年国 民健康・栄養調査結果の概要, p27, http://www.mh/w.go.jp/ houdou/2009/11/dl/h1109-b

5 ）池田順子，福田小百合，村上俊男，河本直樹：青年女子 の瘦せ志向一栄養系短期大学学生の 14 年間の推移一, 日本 公衛誌，55，11，777-785（2008）

6 ）金本めぐみ，横沢民男，金本益男：思春期女性の身体意 識と食行動に関する研究，上智大学体育，38，11-21（2005）

7）鈴木恵美，牧川優：瘦身願望を持った女子学生に対する ライフスタイル改善のための取り組み, 園田学園女子大学
論文集，41，25-32（2007）

8 ）浅井千佐子：短大生における朝食の実態調査に関する一 考察, 東大阪大学・東大阪短期大学部教育研究紀要, 4 , 105-108（2007）

9）木村友子, 加賀谷みえ子, 福谷洋子：女子大学生とその 母親の生活行動並びに食生活状況の実態調査, 栄養学雑誌, $50,6,325-336$ (1992)

10）花戸愛子, 上地加容子, 木村恵子, 佐藤泉, 杉原麻起, 山下まゆ美 : 短期大学生の食生活の実態と食育への取り組 み, 奈良佐保短期大学紀要，15，57-63（2007）

11）五島淑子，大石奈津美，竹中りえこ，古川和樹：朝食加 らみた大学生の食行動, 研究論叢人文科学・社会科学, 53 ( 1), 31-50 (2003)

12）斉藤禮子，原田まつ子，関口紀子，林あつみ，加藤栄子， 女鹿紀子：女子短大の家庭に打ける食生活状況の一考察, 東京家政大学研究紀要，33，35-39（1993）

13）内山聡子，小林幸子：若年女性に打ける瘦せ願望と食生 活状況，和洋女子大学紀要 (家政系編)，43，135-146（2003）

14）渡辺周一, 山沢和子, 佐竹泰子, 松井信子, 真鍋良子, 上野良光，大森正英：青年期女子の体重観と日常生活，東 海女子短期大学紀要，23，91-105（1997）

15）原田まつ子：教育的要因㧍よび精神身体的要因と食品嗜 好, 栄養学雑誌, 46, 1，27-33 (1998)

16）尾峪麻衣，高山智子，吉良尚平：女子大学生の食生活状 況および体型・体重調節志向と疲労自覚症状との関連, 日 本公衛誌，52，5，387-397（2005）

17）原田まつ子：栄養士課程の女子学生における食生活要因 と自覚症状の関連性について, 栄養学雑誌, 46, 4, 175184 (1998)

18）天本理恵, 堂薗美奈, 外山健二 : 栄養学科学生に拈ける 食生活の実態と不定愁訴との関連，西南女学院大学紀要，8, 75-85（2004）

19）黑田育代，真鍋祐之，高橋史江，水江文香，岡本美紀, 川内美樹，前田衣美子，舟森美里，磯部七絵，金子一郎， 西田江里, 熊井まどか, 滝本圭子, 桝屋由美子, 山本孝史, 岩堀修明, 長岡寬明, 小林秀光, 榊原隆三, 野村秀一, 竹 本泰一郎：学生の健康及び食生活意識と血液検査值の関係 に対する一考察，長崎国際大学論叢，6，215-228（2006）

20）齋藤さな恵, 下田妙子：女子大学生の栄養素等摂取量と 欠食との関連，東京医療保健大学紀要，1，31-37（2006）

21）東川尅美, 古崎和代, 菊地和美, 前田雅子, 平井和子 居住形態からみた女子大生の健康と食生活との意識調査, 日本食生活学会誌，15，1，12-21（2004）

22）江田節子：女子学生の排便傾向と食習慣との関連, 山形 県立米沢女子短期大学紀要，36，113-119（2001）

23）後藤千穂, 徳留裕子：女子短大生の排便状況と生活習慣, 名古屋文理短期大学紀要，24，81-86（1999）

24）坂口淳子, 小林修平 : 生涯にわたる健康づくりを志向した 管理栄養士養成課程の学生の食物摂取状況の実態と評価, 和洋女子大学紀要, 43 家政系157-164（2003）

25）加藤由美子, 原田まつ子：女子短大生の骨密度区分でみ た疲労度・朝食パターン・食意識, 帝京短期大学紀要, 15 , 43-47(2008)

26）若本ゆかり，中西裕美子：女子大学生の音響的評価值 （OSI）に関連する因子の検討一女性の QOL 維持向上のた めの栄養 ·健康教育の知見から 栄養学雑誌，67，2，6575 (2009)

27）曽我部夏子，丸山里枝子，佐藤和人，五関一曽根正江： 
大学生におけるボディ・マス・インデックスと食生活および 骨量との関連性について, 栄養学雑誌, 67, 2, 58-64 (2009)

28）石森眞子, 藤原美佐子, 梅村詩子：学生の朝食の欠食と 循環器疾患危険因子との関連, 東京文化短期大学紀要, 24 , 19-24 (2007)

29）小原章裕, 松久次雄, 山口清: 大学生活に扔ける骨密度 と食生活の関係について, 日本食生活学会誌 $15,3 ， 170$ -177 (2004)

30）小野廣紀, 柏下淳, 青山武史, 青木良光, 松宮良子, 武 藤吉徳, 杉浦浩子, 石原多佳子, 牧野茂徳, 山田光子, 後 閑容子, 伊藤孝治, 若林和夫, 轟伊佐雄: 岐阜大学学生の 食生活調査（食品群の摂取状況）一自宅外通学生㧍よび男 子学生の食事は悪いか? 一, 岐皁市立女子短期大学研究紀 要第52, 127-133 (2003)

31）相川り急子, 彦坂令子, 近藤恵久子, 北島裕子, 八倉巻 和子：女子大生の栄養摂取と生活時間一体脂肪率と栄養摂 取 - 生活時間 - 自覚的症状一, 大妻女子大学家政研究紀要, 40, 123-131 (2004)

32）時枝久子, 滝澤和子, 福司山エッ子, 徳田和子 : 女子 学生の食に関連する生活について（第 1 報）一居住形態別 による比較一, 九州女子大大学紀要，33，4，41-56（1997）

33）時枝久子, 横山美栄子, 小林久美：若年単身女性の食生 活の実態，九州女子大大学紀要，32，2，51-60（1996）

34）近藤恵久子, 相川り急子, 彦坂令子, 八倉巻和子：女子 大生の栄養摂取と生活時間一自宅生・寮生と下宿生に扮け る学年別検討, 大妻女子大学家政研究紀要, 38, 61-69 (2002)

35）常松濡子, 渡来玲子：1 人暮らし女子大生の栄養摂取状況, 東京家政学院大学紀要, 42, 63-68 (2002)

36）川端輝江, 西村早苗, 縄田敬子, 足立尚子, 武藤志真子, 山内喜昭, 高橋勝美, 藤倉純子, 岩間範子, 香川芳子 : 女 子大生の体格と食物摂取状況一 30 年前と現在の比較, 女子 栄養大学紀要, 39, 25-32（2008）

37）原田まつ子, 小風暁, 吉田正雄, 内田淑子, 関口夏奈子, 増田由美, 照屋浩司, 高島豊 : 新しく開発された「摂取時 間带を含む食事メニュー式栄養調査（MMITQ）」の妥当性, 日本食生活学会誌，16，4，306-312（2006）

38）健康 - 栄養情報研究会編 厚生労働省 平成14年国民健
康・栄養の現状, p115, 第一出版, 東京 (2004)

39）厚生科学審議会地域保健健康増進栄養部会; 「健康日本 $21 」$ 中間評価報告書 (2007)

40）独立行政法人 国立健康 - 栄養研究所監修 山本茂, 由 田克士編 日本人の食事摂取基準（2005年版）の活用, p.39， 第一出版, 東京 (2005)

41）加來卵子, 八尋俊子：女子短大生の起床時の生活行動の 実態，西南女子学院短期大学研究紀要，49，21-27（2003）

42）内閣府食育推進室, 大学生の食に関する実態・意識調査 報告書, http://ww8.cao.go.jp/syokuiku/more/reseach/pdf/ syoku-gaiyo.pdf-, (2009)

43）木村修一, 食事回数と生体リズム 食事のタイミングー 時間生物学からみた食物摂取の智恵一, 食の科学 228,14 -21 (1997)

44）楱葉繁紀, 脂肪組織における時計遺伝子の機能 メタボ リックシンドロームとの関わりについて：ファルマシア, $42,6,553-556$ (2006)

45）香川靖男編 時間栄養学 時計遺伝子と食事のリズム, 22-25女子栄養大学出版部, 東京 (2009)

46) Lisa R. Purslow, Manjinder S. Sandhu, Nita Forouhi, Elizabeth H. Young, Robert N. Luben, Ailsa A. Welch, Kay-Tee Khaw, Sheila A. Bingham, and Nicholas J. Wareham : Energy Intake at Breakfast and Weight Change : Prospective Study of 6, 764 Middle - aged Men and Women, Americian Joumal of Epidemiology, 1. 167, 2, 188-192 (2008)

47) Albert J. Stunkard, William J. Grace and Harold G. Wolff, : The Night-eating Syndrome, American Journal of Medicine 19 78-86 (1955)

48）矢富悦子, 平賀裕之: 若年層における夕食時刻が健康に 及ぼす影響，産衛誌，48，1033（2006）

49）金子誉, 里誠, 佐々山竜一, 小林光信, 佐久間雅史, 佐 宗真由美, 佐相万里子, 田口和之：医学科学生における食 生活の実態と夜間摂食症候群 山梨医大紀要 18, 7-10 (2001)

50）金子誉, 嶋崎眞紀, 島田八重子, 夜間摂食症候群とその 内分泌学的特徴 産衛誌 44, 264（2002） 